\title{
CNTRL wt Allele
}

National Cancer Institute

\section{Source}

National Cancer Institute. CNTRL wt Allele. NCI Thesaurus. Code C97892.

Human CNT RL wild-type allele is located in the vicinity of 9q33.2 and is approximately 103 $\mathrm{kb}$ in length. This allele, which encodes centriolin protein, is involved in both cell cycle regulation and cell division. A chromosomal translocation $\mathrm{t}(8 ; 9)(\mathrm{p} 12 ; \mathrm{q} 33)$ of this gene and the FGFR1 gene is associated with stem cell myeloproliferative disorder. 